\title{
Chia Seeds (Salvia hispanica $L$ ) Wild Plant Rich in
}

\section{Nutrients}

Virginia Melo-Ruíz ${ }^{1}$, Beatriz Schettino-Bermúdez ${ }^{2}$, Jesús Rodríguez-Diego ${ }^{2}$, Rafael Díaz-García ${ }^{3}$, Concepción Calvo-Carrillo ${ }^{3}$ and César Gazga-Urioste ${ }^{1}$

1. Biologic Systems Department, Metropolitan Autonomous University, Mexico City 04960, Mexico

2. Agricultural and Animal Production Department, Metropolitan Autonomous University, Mexico City 04960, Mexico

3. Health Care Department, Metropolitan Autonomous University, Mexico City 04960, Mexico

4. Department of Animal Nutrition, National Institute of Medical Sciences and Nutrition "Salvador Zubirán”, Mexico City 14080, Mexico

\begin{abstract}
Chia seeds played an important role in different ethnic group's diet at pre-Hispanic times. Later, it was domesticated due to high demand by the population and nowadays it's cultivated in several states of Mexico. However, seeds are not part of the Mexican average diet. The aim of this research was to asses Chia seed's macronutrients and promote consumption among population to decrease malnutrition. Chia seeds were collected at Puebla State (2015) and analyzed according to AOAC [1] methods. Data obtained (g/100 g dry basis) were: proteins $18.51 \%$; lipids $31.33 \%$; minerals $4.45 \%$; fiber $24.45 \%$; soluble carbohydrates $21.38 \%$. Chia seeds absorb water about ten times its weight, is gluten free and contain a good amount of proteins, indispensable for human life. In addition, Chia seeds have a balanced amount of polyunsaturated essential lipids, which are important for brain function, minerals, fiber and soluble carbohydrates. Chia seeds are available all year and are well accepted by all social groups, therefore it could be a good option to improve human health.
\end{abstract}

Key words: Chia seeds, nutraceutic benefits, nutritional plant.

\section{Introduction}

Chia (Saviahispanica L) of the mint family, lamiaceae, is a natural plant native from Mexico cultivated in several states, the seeds were a staple food in the diet of the ancient Aztecs and Mayans, this shrub grows in central regions of Mexico and is available almost all year [2]. After the Spanish conquest, Chia seeds were banned due to its association with Aztec religion, and later, during colonial times, consumption of this ancient super food was left out of the Mexican diet for a while, however, due to their high nutraceutic value, nowadays consumption of these healthy seeds has been increased and used to treat a wide range of diseases including skin problems, insulin resistance, joint inflammation

Corresponding author: Virginia Melo-Ruíz, Ph.D., research field: unconventional nutritious food. and cardiovascular problems to name a few. Chia seeds are loaded with proteins, including essential amino acids, fiber, lipids, vitamins with antioxidant properties which have strong immunological benefits and minerals such as zinc that plays an important role in the antioxidant defense system of the human body, even though it is not an antioxidant on its own [3-5]. The purpose of this study is to assess macronutrients and micronutrients of Chia seeds and to provide an overview of the health benefits of Chia seeds based on the findings of different recent scientific studies.

\section{Materials and Methods}

\subsection{Sample Collection}

Chia seeds were collected [6] at Atzitzihuacan, a town and municipality at Puebla State, south-eastern Mexico. This region is part of the Mixteca and its geographical coordinates are parallel $18^{\circ} 46^{\prime} 00^{\prime \prime}$ and 
$18^{\circ} 53^{\prime} 24^{\prime \prime}$ north latitude and meridians $98^{\circ} 28^{\prime} 54^{\prime \prime}$ and $98^{\circ} 42^{\prime} 00^{\prime \prime}$ west longitude. The zone has a semi-arid and sub-humid climate with rains in summer.

\subsection{Determination of Moisture Content}

Moisture content of samples was determined using the direct drying method. Homogenized sample (10 g) was dried in an oven at $60{ }^{\circ} \mathrm{C}$ for $24 \mathrm{~h}$. The samples were powdered in a mortar then passed through a 60 mesh size. The obtained fine powder was used for further analysis.

\subsection{Determination of Ash}

Ash was obtained by incinerating at $650{ }^{\circ} \mathrm{C}$ in a muffle furnace for $6 \mathrm{~h}$ to a constant weight, to eliminate organic matter.

\subsection{Determination of Lipid Content}

Lipid content determination was performed by the semi continuous solvent extraction method (AOAC Method 934.01) [1] as follows: ten grams of the sample were extracted with $180 \mathrm{~mL}$ petroleum ether on a Soxhlet apparatus (Sigma-Aldrich, Mexico City, Mexico) for $10 \mathrm{~h}$. Petroleum ether was removed by evaporation and the lipid residue was weighed. All samples were analyzed by triplicate and the results are expressed as $\mathrm{g} / 100 \mathrm{~g}$ dry basis of sample.

\subsection{Determination of Protein Content}

Protein content of the sample was determined according to the principle of the Kjeldahl method (AOAC Method 945.01) [1]. The sample (1 g) was digested with $15 \mathrm{~mL}$ of concentrated sulphuric acid, using an electrically heated aluminum block digester. The resulting digest was diluted and then made

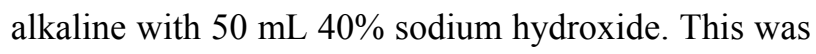
followed by rapid steam distillation of ammonia from the diluted digest into $25 \mathrm{~mL}$ of $4 \%$ boric acid for manual titration with $0.2 \mathrm{~N}$ hydrochloric acid. A conversion factor of 6.25 was used to convert the measured nitrogen content to protein content. All samples were analyzed in triplicate and the results are expressed as $\mathrm{g} / 100 \mathrm{~g}$ dry basis of sample $[7,8]$.

\subsection{Determination of Total Minerals}

Ash content was determined using a dry ashing method. The sample $(10 \mathrm{~g})$ was incinerated in a cold muffle furnace set at $550{ }^{\circ} \mathrm{C}$ until whitish/greyish ash was obtained. Organic matter was burned off and the remanent inorganic material was cooled and weighed. Ash solution for determination of mineral composition was then prepared by dissolving the resulting ash in $100 \mathrm{~mL}$ of HCl1N [9], $50 \mathrm{~mL}$ were taken for the determination of sodium, calcium, potassium, iron, copper, zinc and magnesium content by atomic absorption spectroscopy [10] using a Varian SpectrAA-250 Plus apparatus, which was calibrated with nitric and percloric acid solution and three standards according to the equipment's manual. All samples were analyzed in triplicate. The results are expressed as g/100 g FW of sample for ash content and $\mathrm{mg} / 100 \mathrm{~g} \mathrm{FW}$ of sample for each mineral element. Phosphorus was determined by colorimetry [11].

\subsection{Vitamins A and E Analysis}

An aliquot of the homogenized sample $(0.5 \mathrm{~g} \pm 0.05$ g) was weighed into a $50 \mathrm{~mL}$ centrifuge tube and 2 $\mathrm{mL}$ ethanolic pyrogallol $(2 \%)$ and $2 \mathrm{~mL}$ of ethanolic potassium hydroxide $(10 \%)$ were added. After vigorous shaking, samples were incubated in the dark for $18 \mathrm{~h}$. The sample was then shaken and $1 \mathrm{~mL}$ of the mixture was transferred into a $15 \mathrm{~mL}$ conical tube. 2 $\mathrm{mL}$ of petroleum ether and $1.5 \mathrm{~mL}$ of nanopure deionized water were added, and the sample was mixed. After the two phases separated, the organic layer was transferred into another $15 \mathrm{~mL}$ conical tube which was then wrapped in aluminum foil to minimize light exposure. The extraction step was repeated twice more with only $2 \mathrm{~mL}$ of hexane and the extracted organic phases were pooled. If an emulsion occurred during the extraction, ethanol was added. 
Organic phase was then dried under nitrogen. The sample was re-dissolved in methanol and filtered through a Sri Titan PTFE filter $(0.45 \mu \mathrm{m})$, the final volume was $400 \mu \mathrm{L}$. For HPLC (High Performance Liquid Chromatography), $50 \mu \mathrm{L}$ of both retinyl acetate $(2 \mathrm{mg} / \mathrm{L})$ and $\alpha$-tocopherol acetate $(150 \mathrm{mg} / \mathrm{L})$ were added to correct variations in injection volume. Retinol and $\alpha$-tocopherol standards at three concentrations were extracted as samples to determine recovery; mean recoveries were $85.4 \%$ and $39.5 \%$ respectively. HPLC analysis was performed on a Supercosil LC-18 $(250 \times 4.6 \mathrm{~mm}$ i.d., $5 \mu \mathrm{m})$ (Supelco, Sigma-Aldrich Canada Ltd., Oakville, ON, Canada) equipped with a Pelliguard LC-18 column (Supelco, Sigma-Aldrich Canada Ltd.) connected to a Gold HPLC system (Beckman Coulter, Mississauga, Ont, Canada) with a programmable pump (Model 126), a diode array detector (Model 168) and a Gilson auto-injector (model $231 \mathrm{XL}$ ). The sample $(100 \mu \mathrm{L})$ was eluted with $100 \%$ methanol at a flow rate of 1 $\mathrm{mL} / \mathrm{min}$ and monitored at 325 and $280 \mathrm{~nm}$ for vitamins $\mathrm{A}$ and $\mathrm{E}$, respectively. Peak areas were determined by the HPLC system building software (Gold version 8.1, Beckman Coulter) and the concentrations were calculated with a 5-points calibration curve with external standards. The external standard concentrations ranged from 0.66 to 6.60 $\mathrm{mg} / \mathrm{L}$ and $30.22-302.18 \mathrm{mg} / \mathrm{L}$ of all-trans-retinol and $\alpha$-tocopherol, respectively.

\subsection{Vitamin C Analysis}

$100 \mathrm{~g}$ of sample and $100 \mathrm{~g}$ of metaphosphoric acid (3\%) were ground in a blender. A portion of the ground sample was weighed to contain $10-15 \mathrm{mg}$ of ascorbic acid (10-20 g of ground sample), transferred to a $100 \mathrm{~mL}$ volumetric flask, filled up to the mark with metaphosphoric acid (3\%) and filtered. $2 \mathrm{~mL}$ of the filtered sample were placed into a volumetric flask, then $2 \mathrm{~mL}$ of acetate buffer solution ( $\mathrm{pH} 4.0$ ), $3 \mathrm{~mL}$ of 2.6-Dichlorophenolindophenol solution (125 mg of 2.6-Dichlorophenolindophenol were dissolved to 100
$\mathrm{mL}$ distilled water, then a $18 \mathrm{~mL}$ aliquot were transferred and diluted to $100 \mathrm{~mL} .1 \mathrm{~mL}$ of this solution equals to $0.1 \mathrm{mg}$ ascorbic acid) and $15 \mathrm{~mL}$ of xilene were added quickly. After 10-15 s of vigorous shaking, phase separation was allowed and the aqueous phase was removed by pipetting. Then, water remains were eliminated by adding anhydrous $\mathrm{Na}_{2} \mathrm{SO}_{4}$. Absorbance was determined by U.V spectrophotometry at $520 \mathrm{~nm}$ using xilene as blank. The concentrations were calculated with a 5-points calibration curve with external standard. The standard concentrations ranged from $2.27 \mathrm{mg} / \mathrm{L}$ to $9.09 \mathrm{mg} / \mathrm{L}$ of ascorbic acid [13, 14].

\subsection{Determination of Fiber}

Determination of raw fiber in the sample $(10 \mathrm{~g})$ was performed by acid hydrolysis digestion with $\mathrm{H}_{2} \mathrm{SO}_{4}$ $0.255 \mathrm{~N}$ followed by alkaline hydrolysis digestion with $\mathrm{NaOH} 0.313 \mathrm{~N}$ in a Labconco apparatus (Labconco corporation, Kansas city, Mo. USA). Sample was analyzed in triplicate and results are expressed as $\mathrm{g} / 100 \mathrm{~g}$ dry basis.

\subsection{Determination of Total Available Carbohydrate} Content

The amount of carbohydrates was determined by difference.

$$
\begin{gathered}
\text { carbohydrate } \%=100 \%-[(\text { protein } \%)+ \\
(\text { lipids } \%)+(\text { minerals } \%)+(\text { fiber } \%)]
\end{gathered}
$$

\subsection{Determination of $A A$}

Chia seeds sampled for amino acid analysis was hydrolyzed with $6 \mathrm{~N} \mathrm{HCl}$ for $24 \mathrm{~h}$ at $110{ }^{\circ} \mathrm{C}$ and evaporated under vacuum steam; the sample was then re-suspended in the NA-S buffer and injected to the system. For the analysis of methionine and cysteine, samples were oxidized with performicacid before hydrolysis. AA were determined by HPLC, using an automatic auto-analyzer Beckman System Gold model 6,300 that includes a solvent module $120 \mathrm{AA}$, post column reactor 232 , detector 166 , auto-sampler 507 , a 
column of cation Exchange resin $(3 \times 250 \mathrm{~mm}$ spherogel AA sodium column sulfonated polystyrene-divinylbenzene copolymers), eluted with a gradient of buffers with a concentration of $0.2 \mathrm{M}$ to $2 \mathrm{M}$ of citrate and $\mathrm{pH} 3.1$ to 5.6 and a computer work station. Triplicate analyses were performed for each sample.

\section{Results and Discussion}

Chia seeds (Salvia hispanica L) (Fig. 2) contain 18.51\% of high quality proteins (Table 1), that are essential for human needs, such as growth and body mass.

Proteins are built from various combinations of 20 amino acids which are its building blocks. Chia seeds contain 17 of the 20 amino acids (Table 2), including Leucine, Isoleucine, Lysine, Methionine, Phenylanaline, Threonine and Valine (required for adults) in addition to Histidine and Arginine (required for children plus the 7 amino acids previously mentioned). Among the most important functions of amino acids are [3, 4, 15]:

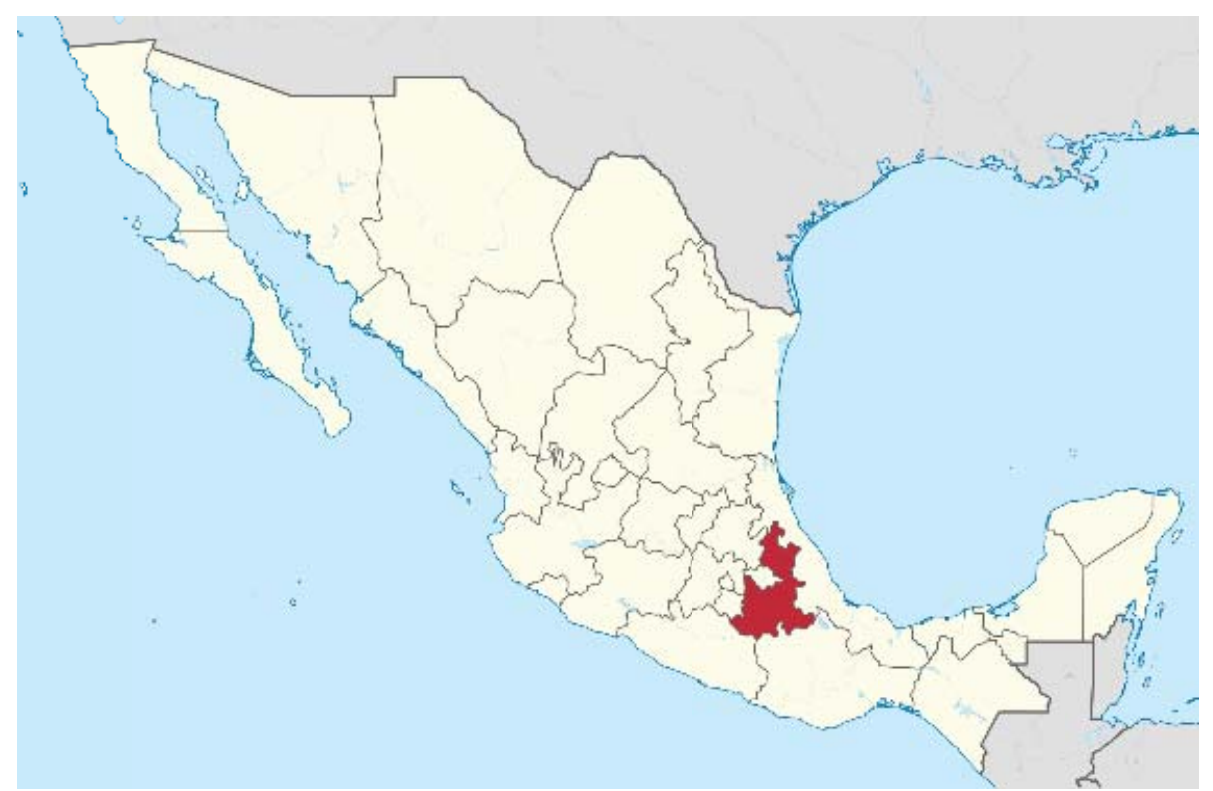

Fig. 1 Map of Mexico, Puebla State in red.

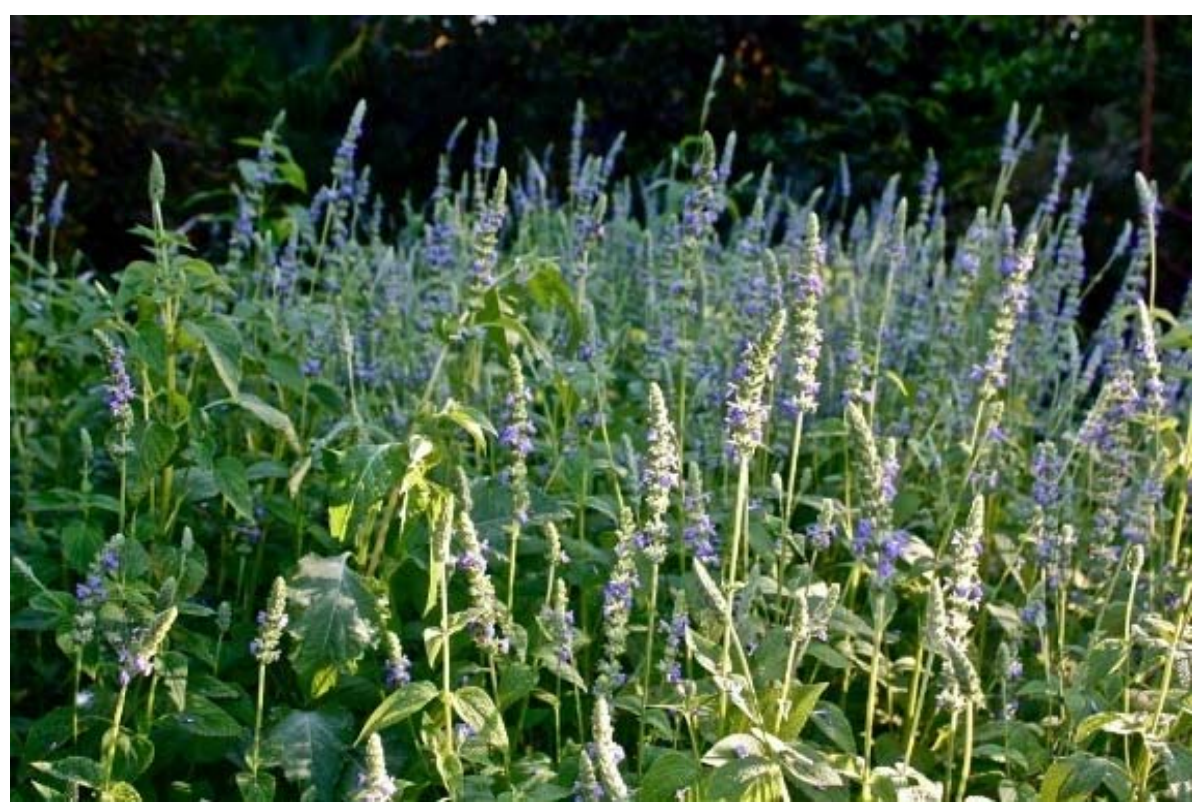

Fig. 2 Image of Chia (Salvia hispánica $L$ ) shrub. 
Table 1 Moisture and macronutrient composition of Chia seeds ( $\mathrm{g} / 100 \mathrm{~g}$ dry basis).

\begin{tabular}{ll}
\hline Component & $\mathrm{g} / 100 \mathrm{~g}$ \\
\hline Moisture & 3.8 \\
Drysample & 96.2 \\
Proteins & $18.51 \pm 1.1$ \\
Lipids & $31.33 \pm 0.9$ \\
Minerals & $4.43 \pm 1.2$ \\
Fiber & $24.45 \pm 0.5$ \\
Soluble carbohydrates & 21.38 \\
\hline
\end{tabular}

All values are mean of triplicate determination.

N Kjeldalh $\times 6.25=$ Proteic Nitrogen.

Soluble carbohydrates calculated by difference.

Table 2 Amino acid content in Chia seeds (g/16 g N).

\begin{tabular}{llll}
\hline Amino acid & $\mathrm{g} / 16 \mathrm{~g} \mathrm{~N}$ & Amino acid & $\mathrm{g} / 16 \mathrm{~g} \mathrm{~N}$ \\
\hline Asparticacid & 7.24 & Methionine & 0.56 \\
Glutamicacid & 12.91 & Isoleucine & 3.18 \\
Tryptophan & $\mathrm{ND}^{*}$ & Leucine & 5.54 \\
Threonine & 3.93 & Tyrosine & 2.85 \\
Serine & 4.75 & Phenylalanine & 4.55 \\
Glycine & 4.35 & Lysine & 4.54 \\
Alanine & 4.36 & Histidine & 2.65 \\
Valine & 5.21 & Arginine & 7.91 \\
Cysteine & 1.54 & Proline & 4.45 \\
\hline
\end{tabular}

*ND: Not determined.

- Alanine; major component of connective tissue, a key intermediary for the glucose-alanine cycle which, allows muscles to get energy from amino acids and helps immune system build up.

- Arginine; is a precursor for creatine, increases the secretion of insulin and glucagon, stimulates hormones release, aids injury rehabilitation, collagen formation and stimulation of immune system.

- Aspartic acid; is important for carbohydrates transformation into energy in muscles, participates in the immune system and immunoglobulins formation and reduces ammonia levels after exercise, is also precursor of asparagine.

- Cystine; contributes to the formation of strong connective tissue and for tissue's antioxidants actions, stimulates blood cells activities and diminishes pain from inflammation processes. It is essential for hair and skin formation.

- Glutamic acid; is a precursor of glutamine, proline, arginine, ornithine and glutathione, it is a source of energy and is very important for the brain and other amino acids metabolism.

- Glycine; is part of the structure of hemoglobin and cytochromes (enzymes involved in energy production), produces glucagon which mobilizes glycogen.

- Histidine; contributes to absorption of ultraviolet radiation on skin, it is important for the production of red and white blood cells. It has been used for the treatment of rheumatoid arthritis and digestive ulcers.

- Isoleucine; is a branched chain amino acid used by muscle tissue for energy, prevents muscle wasting in debilitated individuals and it's essential for hemoglobin formation.

- Leucine; a branched chain amino acid that is used as an energy source and helps reducing muscle protein breakdown, modulates the uptake of brain neurotransmitter precursors and releases encephalins, which inhibits pain signals entering the nervous system. 
- Lysine; is an amino acid which low levels in humans results in a slow protein synthesis, affecting connective tissue and muscles, it also inhibits viruses and aids bone growth by means of collagen formation.

- Methionine; is a precursor of Cystine that increases antioxidant levels and reduces cholesterol, it also helps removing toxins from the liver.

- Phenylalanine; is the precursor for Tyrosine formation, it participates in the learning and memory processes and has an important participation on collagen production.

- Proline; participates in the formation of connective tissue and heart muscle, it is a constituent of collagen, used to provide muscles energy.

- Serine; important for cell energy production, aids in memory and nervous system functions and produces immunoglobulins for immune system.

- Threonine; prevent fat build-up in the liver and is an important component of collagen.

- Tyrosine; is a precursor for Dopamine neurotransmitters, as well as thyriod and growth hormones and melanin.
- Valine; is a branched chain amino acid that is not processed by the liver and helps the uptake of other neurotransmitter precursors.

As table 1 shows, Chia seeds have a high amount of lipids (31.33\%), of which $64.60 \%$ are $\omega-3$ and $18.34 \%$ are $\omega-6$ fatty acids (Table 3 ). The ratio $\omega-3 / \omega-6$ in Chia is 3: 1 , which is important since people need more $\omega-3$ than $\omega-6$ fatty acids. In humans, $\omega-3$ fatty acids, are involved in the synthesis of EPA (eicosapentaenoic acid) and DHA (docosahexaenoic acid), process that depends on each individual's metabolism. In addition, fatty acids are important in hearth's protection [16-19].

On table 4 it can be seen that Chia seeds are an excellent source of minerals such as calcium and magnesium, needed for strong bones and a healthy nervous system. Iron, zinc and copper are contained in a balanced ratio, essential to prevent anemia. In a similar way, the low content of sodium helps to prevent cardiovascular problems.

The content of vitamins A, E and C (Table 5) confer important antioxidant properties to Chia seeds

Table 3 Fatty acid composition of Chia seeds.

\begin{tabular}{lll}
\hline Acid & Fattyacid & $\%$ \\
\hline Palmitic & C16:0 & $7.09 \pm 0.24$ \\
Stearic & C18:0 & $3.33 \pm 0.22$ \\
Oleic & C18:1n9C & $6.62 \pm 1.59$ \\
Linoleic & C18:2n6C & $18.34 \pm 0.63$ \\
Linolenic & C18:3n3C & $64.60 \pm 0.02$ \\
\hline
\end{tabular}

Table 4 Mineral composition of Chia seeds (mg).

\begin{tabular}{ll}
\hline Mineral & $\mathrm{mg}$ \\
\hline Sodium (Na) & $9.5 \pm 1.6$ \\
Potassiun (K) & $715 \pm 2.1$ \\
Calcium (Ca) & $696 \pm 9.9$ \\
Magnesium (Mg) & $355 \pm 3.2$ \\
Iron (Fe) & $7.8 \pm 1.4$ \\
Zinc (Zn) & $3.9 \pm 1.8$ \\
Copper (Cu) & $1.23 \pm 0.6$ \\
Phosphorus (P) & $785 \pm 0.9$ \\
\hline
\end{tabular}

Table 5 Vitamins A, E and C content of Chia seeds.

\begin{tabular}{ll}
\hline Vitamin & Content \\
\hline Vitamin A. Equiv. & $30 \mathrm{IU}$ \\
Vitamin E & $0.83 \mathrm{mg}$ \\
Vitamin C & $3.95 \mathrm{mg}$ \\
\hline
\end{tabular}


that slow down the aging process by means of free radicals destruction, substances naturally produced by normal metabolic processes involved in harmful chemical reactions caused by oxidation. Finally, Chia seeds could improve insulin sensivity and glucose tolerance because of soluble carbohydrates content and due to the fiber, seeds will help digestive system $[4,15]$.

\section{Conclusions}

Chia seeds are a sustainable alternative protein source to meat due to their high nutrient content and lower cost that makes them an accessible option for people. This is a gluten free food, so celiacs can eat it without side effects. It can be consumed in refreshing beverages or as part of stews, cereals, salads and soups.

\section{References}

[1] AOAC. 1995. Official Methods of Analysis, 16th Ed. AOAC International, Washington, DC.

[2] Peña, P. 2000. Cereales y Derivados. In: Astiasarán, I y Martínez, A. (Eds.), Alimentos, composición y propiedades. España. 135-54, McGraw-Hill Interamericana.

[3] FAO/OMS. 1992. Evaluación de la calidad de las proteínas: Informe de una consulta de expertos FAO/OMS. Bethesda, MD, Estados Unidos, Roma.

[4] Melo-Ruíz, V., and Cuamatzi-Tapia, O. 2006. Bioquímica de los Procesos Metabólicos. $2^{\mathrm{a}}$ Edición. Editorial Reverté, S.A. España.

[5] Lloyd, E., Mcdonald, E., and Crampton, W. 1982. Fundamentos de nutrición: Las proteínas y su metabolismo. España: Acribia.

[6] Greenfield, H., and Southgate, D. A. T. 2003. Food Composition Data, 2nd Ed., FAO, Rome.

[7] Osborne, D. R. 1985. Análisis de nutrientes de los alimentos. Acribia. España.

[8] Pearson, D. 1989. Técnicas de Laboratorio para el Análisis de los Alimentos. Acribia. España.

[9] Curry, A. S. R., and Kontt, A. R. 1969. Analyst Flame Atomic Absorption Spectrometry. In: Analytical Methods Varian: 146.

[10] Tee, E. S., Rajam, K., Young, S. I., Khor, S. C., and Zakiya, H. O. 1996. Laboratpry Procedures in Nutrient Analysis of Foods. In: Division of Human Nutrition. Kuala Lumpur. Malasya.

[11] Association of Official Analytical Chemists. 2002. In: Official Methods of Analysis of the Association of Official Analytical Chemists. Horwitz, Ed. Arlington.

[12] Schüep, W. 1997, Análisis de vitaminas en alimentos. En: Producción y manejo de datos de composición química de alimentos en nutrición, (Eds. Morón, C., Zacarías, Y., and de Pablo, S.) Pu. FAO y Universidad de Chile, 195-200, Santiago de Chile.

[13] A.O.A.C. 1990. Official Methods of Analysis. Asociation of Official Agricultural Chemists. USA.

[14] Ranganna, S. 1977. Manual of Analysis of Fruit and Vegetable Products. The Mc Graw Hill Pu. Co. Lim., 94-102, New Delhi.

[15] Baduí, S. 1997. Química de los Alimentos. Ed. Alambra. pp. 125-67, 617-35.

[16] Ayerza, R. 1995. "Oil Content and Fatty Acid Composition of Chia (Salvia hispanica) from Five Northwestern Locations of Argentina." Journal American Oil Society 72: 1079-81.

[17] Ayerza, R. 2000. Chia a New Source of Omega-3 Fatty Acids: from Research to Commercialization. Annual Meeting of the 95 Association for the Advancement of Industrial Crops. Saint Louis, Missouri, USA.

[18] Ayerza, R. 2002. Chia as an Omega-3 Fatty Acid Sourse for Animal and Human Consumption. Office of Arid Lands Studies. The University of Arizona, Tucson, Arizona, USA.

[19] Bagci, E., Vural, M., Dirmenci, T., Bruehl, L., and Aitzetmüller, K. 2004. Fatty acid and Tochochromanol patterns of some Salvia L. species. Naturforsch Z. 59c 305-9. 